\title{
Upaya Optimalisasi Praktik Digital Marketing untuk Meningkatkan Hasil Penjualan Produk Warga Binaan Lembaga Pemasyarakatan
}

\section{Optimization of Digital Marketing Practices to Improve Product Sales of Inamtes in the Productive Prison}

\author{
${ }^{1}$ Inaya Sari Melati, ${ }^{1}$ Margunani, ${ }^{1}$ Saringatun Mudrikah, ${ }^{1}$ Lola Kurnia \\ Pitaloka \\ ${ }^{1}$ Jurusan Pendidikan Ekonomi, Fakultas Ekonomi, Universitas Negeri Semarang
}

Korespondensi: I.S. Melati, inaya.sari@mail.unnes.ac.id

Naskah Diterima: 20 September 2019. Disetujui: 10 Februari 2020. Disetujui Publikasi: 24 Februari 2020

\begin{abstract}
Productive prisons are prisons that are not only a place for guiding inmates (prisoners) in a conventional manner, but can also be a means to encourage the production of a good quality products, therefore productive activities in prisons can be a support for fostering prisoners. In productive prisons, inmates are taught to grow crops, raise livestock to gardening. Lapas Terbuka Kendal, one of productive prisons in Central Java, is currently only filled with 23 inmates who are fostered by the independence of various production activities, namely the agriculture, fisheries and animal husbandry sectors. The results of Lapas Terbuka Kendal production activities can be said to be quite good. Even marketing has been done well, one of them through the website. But unfortunately the existing marketing did not produce maximum results in sales. This is evaluated and resolved in the community service performed. The digital marketing training is a solution given. All officers were enthusiastic in actively participating during the training. By this training, it is expected they could maximize the digital marketing implementation to boost the sales.
\end{abstract}

Keyword: Digital marketing, productive prison, prisoners, production activities, sales.

\begin{abstract}
Abstrak. Lembaga pemasyarakatan (Lapas) produktif merupakan Lapas yang tidak hanya menjadi tempat pembinaan narapidana (warga binaan) secara konvensional, tetapi juga dapat menjadi salah satu sarana untuk mendorong dihasilkannya produk-produk berkualitas, oleh karenanya kegiatan produktif di lapas bisa menjadi penunjang bagi pembinaan terhadap warga Warga Binaan Pemasyarakatan (WBP). WBP diajarkan bercocok tanam, beternak hingga berkebun di Lapas Terbuka. Lapas Terbuka Kendal, salah satu Lapas Produktif di Jawa Tengah, saat ini terisi sebanyak 23 warga binaan yang dibina kemandirian berbagai macam kegiatan produksi yaitu sektor pertanian, perikanan dan peternakan. Hasil kegiatan menunjukkan produksi Lapas Terbuka Kendal dapat dikatakan cukup bagus. Bahkan pemasaran pun sudah dilakukan dengan baik, salah satunya melalui website. Namun sayangnya pemasaran yang ada ternyata tidak membuahkan hasil yang maksimal dalam penjualan. Hal tersebut yang dievaluasi dan dipecahkan pada pengabdian yang dilakukan. Pelatihan pemasaran digital menjadi solusi yang diberikan pada pengabdian ini. Pelaksanaan kegiatan berjalan lancar, seluruh petugas Lapas antusias dalam mengikuti pelatihan. Kegiatan ini diharapkan mereka mampu memaksimalkan fungsi pemasaran digital untuk meningkatkan penjualan.
\end{abstract}

Kata Kunci: Digitalisasi, pemasaran, kegiatan produksi, peningkatan penjualan. 


\section{Pendahuluan}

Lembaga Pemasyarakatan (Lapas) Terbuka Klas II B Kendal merupakan lembaga pemasyarakatan yang berbeda dengan lapas pada umumnya. Lapas kelas II B Kendal secara sah diresmikan dari lapas terbuka menjadi lapas produktif pada tahun 2017. Lapas produktif merupakan lapas yang tidak hanya menjadi tempat pembinaan narapidana (warga binaan) secara konvensional, tetapi juga dapat menjadi salah satu sarana untuk mendorong dihasilkannya produk-produk berkualitas, oleh karenanya kegiatan produktif di lapas bisa menjadi penunjang bagi pembinaan terhadap warga binaan pemasyarakatan. Lapas Terbuka Klas II B Kendal karena secara administratif terletak di Desa Wonosari Kecamatan Patebon, Kabupaten Kendal, Jawa Tengah. Jarak dari Ibukota Kabupaten Kendal sekitar 10 $\mathrm{km}$ ke arah selatan, sedangkan jarak dari Ibukota Provinsi Jawa Tengah (Semarang) sekitar $50 \mathrm{~km}$ ke arah Barat. Lembaga Pemasyarakatan Terbuka Klas II B Kendal memiliki luas lahan kurang lebih 7,5 ha. Bidang lahan tanah tersebut merupakan dataran rendah, perladangan, dan rawa-rawa yang dapat dibuat tambak-tambak. Kegiatan di Lapas produktif yaitu Warga Binaan Pemasyarakatan (WBP) diajarkan bercocok tanam, beternak hingga berkebun agar kelak bisa bermanfaat saat keluar dari Lapas dan dapat berkontribusi di masyarakat. Semangat untuk merevitalisasi lapas sebagai sentra produktif diharapkan dapat mengubah paradigma masyarakat terhadap pembinaan di lapas.

Kapasitas hunian Lapas Terbuka Kendal sejumlah 50 Warga Binaan Pemasyarakatan (WBS) dengan isi penghuni (berdasarkan data pada tanggal 13 Juni 2019) sejumlah 23 WBS. Semua WBS dilibatkan dalam pengelolaan program lapas produktif seperti mengelola lahan pertania, lahan perikanan, dan lahan peternakan, korve masjid dan lingkungan serta mengelola dapur. Pembinaan kemandirian pada para WBS merupakan kegiatan produksi pada sektor pertanian, perikanan, dan peternakan. Pada bidang pertanian, produksi difokuskan pada pertanian kacang hijau, kacang panjang, jagung, sembung dan kacang tanah. Pada bidang perikanan, produksi difokuskan pada budidaya ikan lele, ikan nila, ikan gurame, ikan mujair, dan ikan mas. Sedangkan pada sektor peternakan, kegiatan produksi difokuskan pada budidaya ayam petelur, penangkaran burung love bird, kambing, serta sapi. Seluruh WBS dilibatkan agar dapat menambah soft skill mereka sehingga mereka memiliki soft skill untuk bekerja saat nanti keluar dari lapas. Optimalisasi soft skill dapat mengoptimalkan proses produksi agar dapat meningkatkan penjualan (Rhohman \& Budiretnani, 2018).

Hasil dari kegiatan produksi (pembinaan kemandirian) oleh Lapas Terbuka Klas II B Kendal dapat dikatakan cukup bagus. Hasil panen kacang hijau pada bulan Januari mencapai $450 \mathrm{~kg}$. Jumlah ikan yang dibudidaya untuk jenis ikan lele mencapai 12.000 ekor, ikan nila 10.000 ekor, ikan mas sebanyak 1.500 ekor, dan ikan gurame sejumlah 500 ekor. Peternakan sapi untuk jumlah indukan berjumlah 8 ekor, serta untuk anakan sebanyak 2 ekor, sedangkan untuk kambing sejumlah 9 ekor, dengan jenis kambing peranakan etawa. Jumlah ayam petelur yang dihasilkan juga cukup banyak dengan hasil telur berkisar kurang lebih 20-25 kilogram per hari dari jumlah ayam sebanyak 420 ekor, dan ditargetkan akan terus menambah jumlah ayam petelur hingga 2.000 ekor sehingga diharapkan dapat menyuplai kebutuhan telur ayam untuk wilayah Kendal dan sekitarnya.

Pemasaran hasil pertanian, peternakan dan perkebunan sudah dilakukan oleh Lapas Terbuka Klas II B Kendal pada beberapa tempat seperti penjualan di warung-warung, toko, maupun pada konsumen secara konvensional. Belakang ini, media sosial semakin luas digunakan sebagai saluran promosi pariwisata. Media sosial secara sederhana diartikan sebagai salah satu platform media online untuk mendukung komunikasi secara interaktif. Media sosial banyak dimanfaatkan oleh masyarakat untuk pemasaran yang berbasis digital. Pemasaran berbasis digital 
(digital marketing) adalah terobosan terbaru dalam melakukan pemasaran produk secara online (Purwana dkk., 2017). Strategi digital marketing atau pemasaran online saat ini sangat penting dilakukan dan dapat diyakini lebih efektif serta efesien untuk menjangkau target pasar yang diinginkan. Penelitian Pradiani (2018) pun sudah membuktikan bahwa pemasaran secara online memang dapat meningkatkan hasil penjualan produk karena sekarang ini, masyarakat cenderung lebih suka mencari referensi secara online bahkan membeli produk secara online. Pemasaran secara online juga dapat meningkatkan jangkauan pemasaran yang tidak dapat atau susah dijangkau oleh pemasaran offline (Febriyantoro \& Arisandi, 2018). Berdasarkan hal tersebut, tim Pengabdian menyelenggarakan program pelatihan mengenai pemasaran berbasis digital (digital marketing) untuk mempromosikan produk hasil Lapas Produktif Klas II B Kendal agar dapat lebih luas pemasarannya serta dapat dapat diketahui oleh masyarakat.

\section{Metode Pelaksanaan}

Tempat dan Waktu. Kegiatan pengabdian ini dilaksanakan di Lembaga Pemasyarakatan Terbuka Klas II B Kabupaten Kendal. Kegiatan dilaksanakan selama waktu 3 bulan mulai bulan Juni sampai dengan bulan Agustus 2019.

Khalayak Sasaran. Mitra kegiatan adalah seluruh petugas Lembaga Pemasyarakatan Terbuka Klas II B Kabupaten Kendal sebanyak 30 orang.

Metode Pengabdian. Pada tahap persiapan, Tim pengabdian kepada masyarakat Fakultas Ekonomi Universitas Negeri Semarang memilih Lembaga Pemasyarakatan (Lapas) Terbuka Klas II B Kabupaten Kendal karena Lapas ini merupakan Lapas yang tidak seperti Lapas pada umumnya. Lapas ini merupakan Lapas produktif dan menghasilkan produk-produk yang dapat dijual pada masyarakat. Setelah tim pengabdian melakukan penjajakan dengan melakukan pertemuan dengan petugas Lapas Terbuka Klas II B Kabupaten Kendal diketahui bahwa penjualan produk menjadi salah satu kendala yang dialami oleh Lapas, sehingga tim pengabdian membantu pihak Lapas dalam memasarkan produknya melalui pemasaran digital (digital marketing). Sebelum pelaksanaan, tim pengabdian mematangkan materi pelatihan digital marketing yang nantinya dapat digunakan oleh Lapas. Pada tahap pelaksanaan, tim pengabdian memberikan pelatihan pentingnya melakukan penjualan dengan menyesuaikan perkembangan yang sedang terjadi pada saat ini. Tren penjualan produk yang sedang marak di masyarakat adalah penjualan dengan menggunakan media digital (Guna, dkk., 2013). Tim pengabdian juga memberikan cara-cara melakukan penjualan produk dengan memanfaatkan media sosial serta penjualan pada market place yang sudah tersedia dan banyak digunakan oleh masyarakat Indonesia seperti Bukalapak, Tokopedia, Shopee, Lazada dan lain-lain. Hal ini dilakukan agar produk yang dihasilkan oleh Lapas dapat diketahui oleh seluruh elemen masyarakat sehingga penjualan akan semakin meningkat.

Indikator Keberhasilan. Keberhasilan kegiatan kepada masyarakat ini dilihat dari: meningkatnya pemahaman mitra mengenai pentingnya branding pada digital marketing, terciptanya akun media sosial yang dikelola oleh petugas Lapas yang digunakan untuk mensosialiasikan dan mempromosikan produk, serta pentingnya mitra melakukan sharing mengenai product knowledge pada sosial media berdasarkan pengaturan tempo atau jangka waktu memposting yang tepat.

Metode Evaluasi. Untuk mengevaluasi keberhasilan pelaksanaan kegiatan pengabdian masyarakat ini dilakukan dengan cara: pengecekan terhadap pembuatan akun yang dipilih untuk pemasaran produk secara digital, melakukan pendampingan dalam pembuatan content product knowledge yang menarik yang memperhatikan jangka waktu yang tepat dalam memposting produk. Metode evaluasi terhadap program ini dilakukan dengan mengukur keberhasilan sesuai indikator yang ditetapkan (Kudsiah, dkk.,2018). 


\section{A. Persiapan}

\section{Hasil dan Pembahasan}

Tahap persiapan dilakukan dengan melakukan kunjungan ke Lembaga Pemasyarakatan (Lapas) Terbuka Klas II B Kabupaten Kendal yang dilakukan beberapa kali oleh tim pengabdian. Tim pengabdian melakukan survei mengenai potensi produk yang dihasilkan oleh Lapas. Beberapa produk yang telah dihasilkan oleh Lapas Terbuka Klas II B Kabupaten Kendal hampir semuanya adalah hasil alam yang tanpa mengolahnya terlebih dahulu seperti hasil pertanian, budidaya perikanan dan budidaya peternakan. Selain itu, pihak Lapas menyampaikan bahwa terdapat kendala dalam menjual produk yang mereka hasilkan karena selama ini penjualan baru dilakukan secara konvensional yaitu dengan menjual langsung kepada masyarakat, menitipkan pada warung-warung atau toko, dan melalui website namun penjualan melalui website pun masih kurang maksimal. Sehingga tim pengabdian merasa perlu mengenalkan digital marketing dengan memanfaatkan media sosial dan market place yang tersedia sebagai salah satu alternatif meningkatkan hasil penjualan.

\section{B. Pelatihan dan Pendampingan}

Pelaksanaan kegiatan pengabdian dihadiri oleh 25 warga binaan, 30 petugas Lapas Terbuka Kendal, serta seluruh anggota tim pengabdian Fakultas Ekonomi UNNES pada hari Kamis, 18 Juli 2019 di gedung serbaguna Lapas Terbuka Kelas 2B Kendal yang dimulai pukul 08.00-13.00 WIB. Kegiatan ini mendapatkan sambutan yang sangat hangat dan antusias dari para warga Lapas Terbuka Kendal (Gambar 1 dan 2).

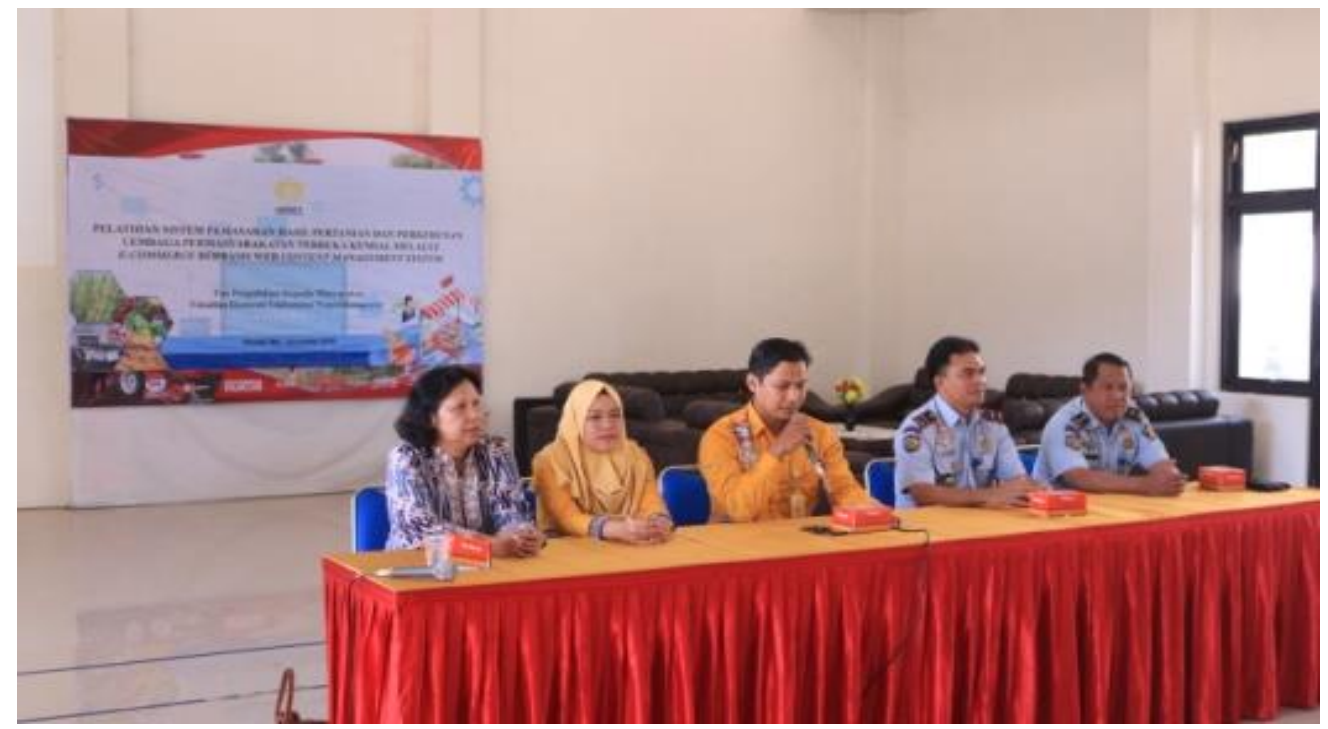

Gambar 1. Pengenalan anggota pengabdian kepada warga Lapas

Kegiatan pengabdian di Lapas Terbuka Kelas 2B Kendal diawali dengan pemaparan materi mengenai penggalian potensi, pemanfaatan sumber daya alam dan teknologi tepat guna yang ada di lingkungan tempat binaan. Teknologi tepat guna adalah teknologi yang sesuai dengan kebutuhan masyarakat, tidak merusak lingkungan, dapat dimanfaatkan dan dipelihara oleh masyarakat secara mudah, serta menghasilkan nilai tambah dari aspek ekonomi dan aspek lingkungan.

Pengelolaan dan penerapan teknologi tepat guna dalam pengelolaan sumber daya alam di lingkungan Lapas Terbuka Kendal dimaksudkan sebagai upaya optimalisasi sumber daya yang dimiliki, memajukan ekonomi, memberikan pelatihan kepada warga lapas, penguatan kapabilitas warga lapas dengan 


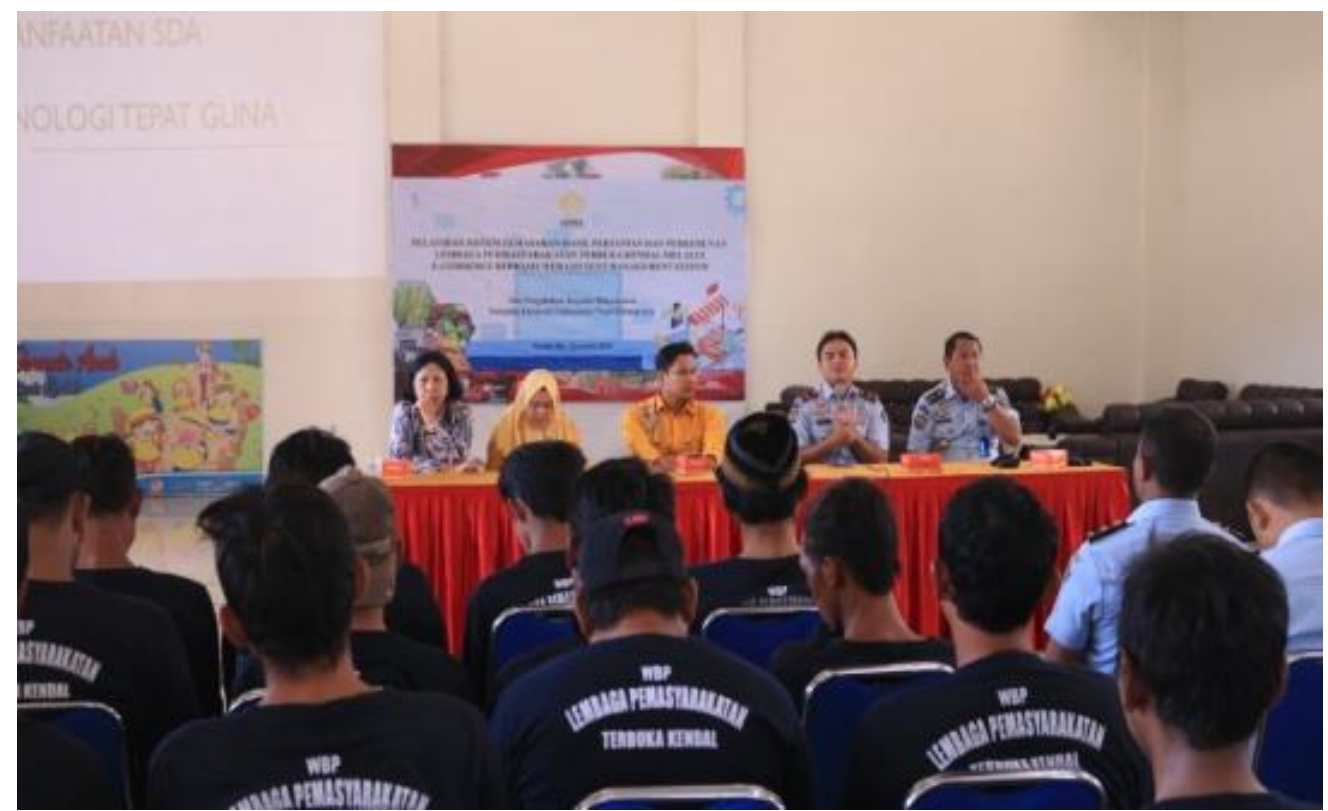

Gambar 2. Pengarahan dari ketua Lapas Terbuka Kendal

mendorong pembentukan, pengembangan dan penguatan kewirausahaan. Warga binaan dan petugas Lapas Terbuka Kendal diajak untuk menggali lebih dalam tentang potensi yang dimiliki dan akan dikembangkan. Pengembangan tidak hanya dilakukan tidak hanya pada tahap pengolahan awal tetapi sampai pada pengolahan dengan inovasi. Kegiatan selanjutnya pengenalan tentang digital marketing atau pemasaran digital (Gambar 3). Digital marketing atau pemasaran berbasis digital merupakan aktifitas atau kegiatan pemasaran dengan serangkaian cara serta teknik yang menggunakan media digital yang bertujaan meningkatkan penjualan. Digital marketing dapat dilakukan dengan berbagi media seperti: website, blog, youtube maupun menggunakan media sosial (Oktaviani \& Rustandi, 2018).

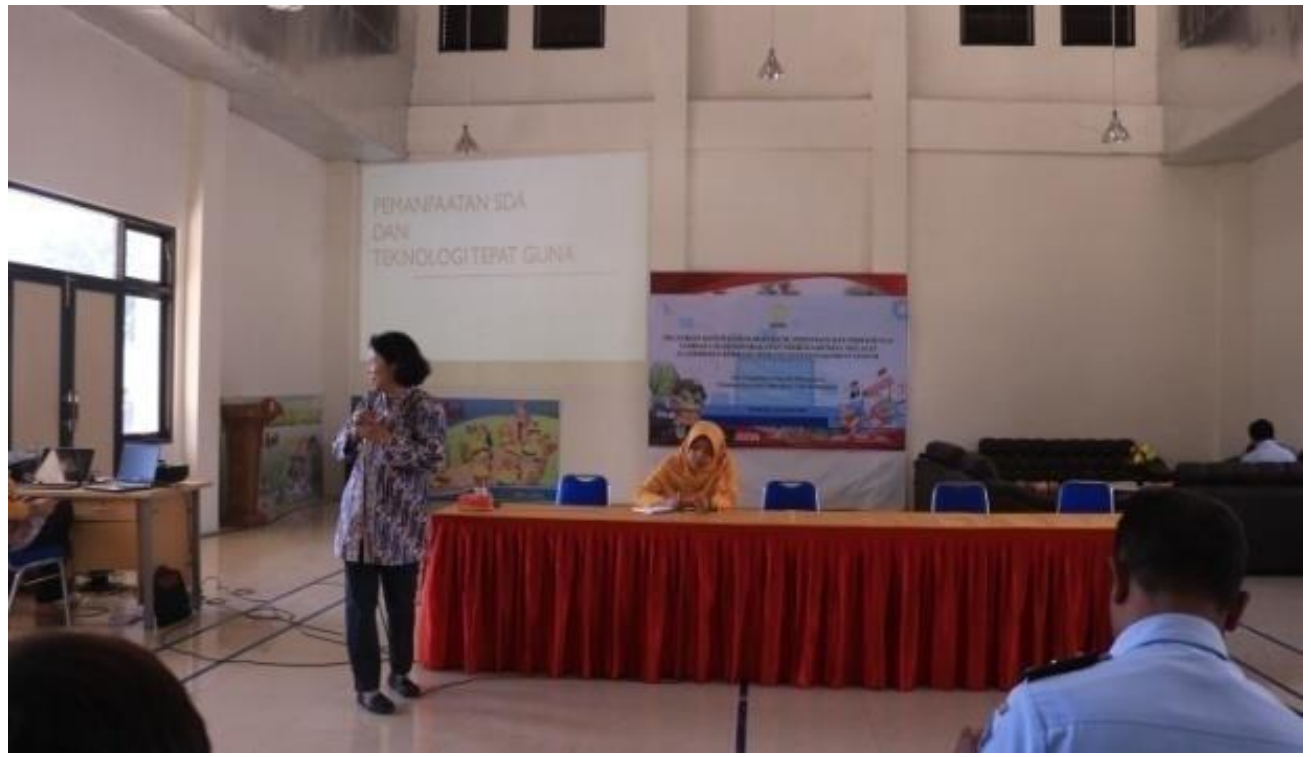

Gambar 3.Pelatihan digital marketing kepada warga Lapas

Beberapa strategi diberikan dalam pengelolaan digital marketing seperti: menentukan media utama apa yang akan dipilih. Sebelum menentukan media apa yang akan dipilih, sebaiknya terlebih dahulu menentukan target pasar yang akan dituju. Menentukan target pasar akan mempengaruhi pemilihan sosial media apa 
yang tepat. Setelah menentukan sosial media yang dipilih, selanjutnya menentukan kepribadian. Penentuan kepribadian harus sesuai dengan bisnis yang dimiliki. Bahasa yang digunakan dalam penyampaian informasi kepada pembeli dapat dilakukan dengan bahasa yang santai, banyak humor, ada juga yang menggunakan bahasa formal dan serius. Hal terpenting dalam menentukan kepribadian, harus sesuai dengan bisnis yang dimiliki. Kepribadian dalam pemilihan bahasa menjadi penting untuk sarana promosi terlebih jika kita mengoptimalkan penggunaan sosial media Instagram. Visual dan bahasa yang menyenangkan serta konsisten dapat menarik lebih banyak pembeli (Gumilar, 2015).

Strategi konten dalam digital marketing juga perlu diperhatikan. Tanpa adanya konten yang menarik, semua hal yang dilakukan dengan social media tidak akan ada hasilnya. Selain strategi konten, strategi promosi juga penting. Dalam strategi promosi pilihlah waktu-waktu yang tepat dan pas untuk melakukan promosi. Walaupun promo disukai oleh konsumen, namun jangan melakukan promo setiap hari karena promo setiap hari dapat membuat konsumen bosan sehingga dapat meninggalkan produk yang dijual. Agar lebih aman, dapat melakukan promosi secara tersirat di dalam sebuah artikel yang bermanfaat atau dalam postingan yang menarik. Alternatif strategi lain agar penjualan produk dengan berbasis digital dapat sukses, antara lain dengan menjalin kerjasama dengan influencer. Social media influencer adalah orang yang memiliki akun sosial media dengan follower yang jumlahnya banyak dan memiliki kemampuan untuk membuat dan mempengaruhi semua followernya. Setelah semua strategi dilakukan, yang terakhir adalam menjalin komunikasi melalui social media. Dengan menjalin interaksi secara personal, maka akan mendapat banyak teman yang lebih loyal terhadap produk yang dijual serta tidak menutup kemungkinan teman tersebut dapat merekomendasikan produk kita kepada teman-teman yang lain. Hal ini bisa menjadi salah satu promosi yang bisa didapatkan secara gratis atau cuma-cuma.

Tahapan berikutnya adalah pelatihan pemasaran digital menggunakan media sosial dan marketplace yang telah tersedia banyak di Indonesia. Pelatihan pemasaran ini ditujukan kepada petugas Lembaga Pemasyarakatan Terbuka Klas II B Kendal. Hal ini dilakukan karena selama ini pemasaran produk hanya baru dipasarkan melalui website, sedangkan media sosial dan marketplace belum mulai digunakan. Media sosial di era sekarang ini menjadi platform yang sangat menarik untuk dieksplorasi dalam kaitannya dengan bagaimana suatu merek mengembangkan kanal pemasaran melalui media sosial dan marketplace. Indonesia memiliki potensi pasar yang sangat besar seiring dengan pertumbuhan adopsi internet dan penggunaan telepon pintar (smartphone).

Berdasarkan penelitian yang dilakukan oleh We Are Social yang bekerjasama dengan Hootsuite, menyebutkan bahwa terdapat 130 juta penduduk Indonesia yang dikatakan aktif di media social. Laporan We Are Social mengungkapkan bahwa total populasi Indonesia mencapai 265,4 juta jiwa, sedangkan pengguna internetnya setengah dari populasi, yakni sebesar 132,7 juta. Apabila dilihat dari jumlah pengguna internetnya, maka dapat dikatakan seluruh pengguna internet di Indonesia sudah mengakses media sosial, dengan 130 juta diantaranya pengguna aktif di media sosial dengan penetrasi 49\%. Selain itu, penduduk Indonesia rata-rata menghabiskan waktu untuk berselancar di internet dengan berbagai perangkat hingga delapan jam 51 menit. Sementara, rata-rata berkecimpung di media sosial dengan berbagai perangkat hingga tiga jam 23 menit. Platform media sosial yang banyak digunakan oleh penduduk Indonesia diantaranya: Facebook, Whatsapp, Instagram, Line, Twitter, Youtube, WeChat dan beberapa media sosial lainnya.

Ditinjau dari sisi penggunaan e-commerce dan online marketplace di Indonesia, menurut Lembaga riset asal Inggris, Merchant Machine, merilis daftar 
sepuluh negara dengan tingkat pertumbuhan e-commerce tercepat di dunia. Indonesia memimpin jajaran negara-negara tersebut dengan pertumbuhan $78 \%$ pada tahun 2018 (https://merchantmachine.co.uk/saturated-sectors/). Jumlah pengguna internet di Indonesia yang lebih dari 100 juta pengguna menjadi salah satu kekuatan yang mendorong pertumbuhan e-commerce. Rata-rata uang yang dibelanjakan masyarakat Indonesia di situs belanja online mencapai US\$ 228 per orang atau sekitar Rp 3,19 juta per orang.

Melihat jumlah pengguna internet yang sangat besar serta pertumbuhan $e$ commerce di Indonesia yang sangat signifikan, hampir dapat dikatakan bahwa peluang melakukan penjualan produk secara online dan memanfaatkan platform bisnis yang telah tersedia cukup menjanjikan. Hal inilah yang melatarbelakangi dalam membantu memasarkan produk yang telah dihasilkan oleh Lapas terbuka Kendal, yang mana penjualan selama ini masih penjualan yang dilakukan masih konvensional.

Setelah memberikan pelatihan tentang pemasaran melalui online, tahapan program selanjutnya adalah mendampingi para warga Lapas Terbuka Kendal dalam pembuatan akun pada platform e-commerce yang banyak tersedia di Indonesia. Platform yang dipilih nantinya sebagai tempat untuk menjual produk-produk yang dihasilkan oleh Lapas Terbuka Kendal meliputi: BukaLapak, Tokopedia, Shopee, Lazada, juga memanfaatkan media sosial seperti Facebook. Setelah diberikan pelatihan pembuatan akun, warga Lapas Terbuka Kendal juga akan didampingi bagaimana menjual produk-produk melalui pengelolaan yang tepat. Menjalankan toko online dengan toko konvensional di dunia nyata kurang lebih sama, dibutuhkan kerja keras, keahlian, pemahaman, promosi permodalan dalam pengelolaannya. Berbeda dengan menjual barang secara konvensional dimana barang atau produk dapat dilihat dan diraba fisiknya dengan detail, maka toko online hanya mengandalkan gambar visualnya saja, oleh karenanya tidak asal memasang gambar. Dibutuhkan penjelasan yang terperinci untuk menimbulkan ketertarikan calon pembeli.

Beberapa hal yang dapat dilakukan dalam pendampingan penjualan produk melalui online pada warga Lapas Terbuka Kendal yaitu agar bisnis onlinenya dapat berjalan dengan sukses yaitu: Menentukan contact person yang jelas dan aktif, bersikap ramah dan sabar, mengadakan diskon, dan membuat perhitungan dan pembukuan.

Setelah program pelatihan pemasaran online, rencana tahap selanjutnya adalah evaluasi program pengabdian. Hal ini dimaksudkan untuk menganalisis dan mengevaluasi sejauh mana ketercapaian program pengabdian. Sehingga menjadi perbaikan untuk program pengabdian selanjutnya. Setelah kegiatan evaluasi program pengabdian, dilakukan penyusunan laporan akhir pengabdian sebagai bentuk pertanggungjawaban kegiatan kepada lembaga penyelenggara pengabdian kepada masyarakat yaitu Universitas Negeri Semarang.

Secara umum warga binaan dan petugas Lapas sebagai peserta pelatihan sangat antusias mengikuti kegiatan pelatihan ini, hal ini tidak terlepas dari ketertarikan peserta setelah diberi pengetahuan dan pemahaman akan pentingnya memanfaatkan digital marketing untuk promosi produk hasil pertanian, perikanan dan peternakan. Bahkan di akhir kegiatan peserta masih terus bertanya dan melontarkan ide-ide secara personal kepada narasumber.

\section{Keberhasilan Kegiatan}

Kegiatan pengabdian kepada masyarakat terkait pemasaran produk berbasis digital (digital marketing) di Lapas Terbuka Klas II B Kabupaten Kendal mendapat apresiasi dari pihak Lapas. Tingginya penggunaan media sosial serta tumbuhnya market place yang sangat signifikan di Indonesia menjadi alasan utama mengapa Lapas perlu mengikuti trend penjualan yang sedang marak berkembang saat ini. 
Indonesia memimpin jajaran negara-negara lain di Asia dengan tingkat pertumbuhan pada tahun 2018 sebesar 78\%. Jumlah pengguna internet yang melebihi dari 100 juta pengguna menjadi salah satu alasan kekuatan yang mendorong pertumbuhan e-commerce. Rata-rata uang yang dibelanjakan oleh masyarakat Indonesia di situs belanja online mencapai US\$288 per orang atau sekitar Rp, 3,19 juta per orang.

Keberhasilan kegiatan kepada masyarakat ini dapat dilihat dari meningkatnya pemahaman bagi petugas Lembaga Pemasyarakatan yang memberikan deskripsi produk yang menarik dibandingkan dengan produk lain karena produk yang dihasilkan merupakan hasil produksi warga binaan. Selain itu, petugas Lembaga Pemasyarakatan juga semakin melebarkan jalur pemasaran produknya melalui beberapa market place yang tersedia serta pada website yang telah dimiliki sebelumnya. Website yang digunakan untuk memasarkan produknya dapat diakses pada: http://lapasproduktifkendal.com/produk/.

Dalam memposting produknya, petugas Lembaga Pemasyarakatan juga saat ini sangat memperhatikan product knowledge sehingga lebih menarik. Selain itu, jangka waktu memposting produk juga sangat diperhatikan. Postingan tidak dilakukan setiap waktu, tapi disesuaikan dengan kebutuhan. Terkadang produk diposting dalam media pemasaran digital 3 hari sekali atau seminggu sekali. hal ini dilakukan agar konsumen tidak merasa bosan dengan postingan yang apabila dilakukan setiap waktu. Mitra menyampaikan bahwa setelah mengaplikasikan digital marketing, banyak masyarakat yang tertarik untuk membeli produknya, tidak hanya yang berasal dari Kabupaten Kendal, namun juga berasal dari luar daerah.

\section{Kesimpulan}

Warga binaan dan Petugas Lembaga Pemasyarakatan Terbuka Klas IIB, Kendal dapat melakukan penjualan produk yang dihasilkan oleh Lapas melalui melalui penjualan berbasis digital (digital marketing). Penjualan dengan berbasis digital tidak hanya dilakukan di website saja, tetapi juga memanfaatkan platform bisnis yang sudah tersedia serta melakukan penjualan dengan menggunakan media sosial. Dampak dari pemanfaatan pemasaran digital adalah semakin banyaknya konsumen yang mengetahui produk yang dijual oleh Lapas serta dapat meningkatkan jumlah penjualan.

\section{Ucapan Terima Kasih}

Penulis menyampaikan terima kasih kepada Universitas Negeri Semarang, seluruh warga binaan dan petugas Lembaga Pemasyarakatan Terbuka Klas IIB, Kendal atas segala bantuan dan kerjasamanya sehingga kegiatan pengabdian masyarakat ini dapat dilaksanakan.

\section{Referensi}

Febriyantoro, M. T., \& Arisandi, D. (2018). Pemanfaatan Digital Marketing Bagi Usaha Mikro, Kecil Dan Menengah Pada Era Masyarakat Ekonomi Asean. JMD: Jurnal Riset Manajemen \& Bisnis Dewantara, 1(2), 61-76. https://doi.org/ 10.26533/jmd.v1i2.175

Gumilar, G. (2015). Pemanfaatan Instagram Sebagai Sarana Promosi Oleh Pengelola Industri Kreatif Fashion di Kota Bandung. Jurnal Imu Politik Dan Komunikasi, $V(2), 77-84$.

Guna, M., Daya, M., Dalam, S., \& Asean, M.E. (2013). Optimalisasi Pemanfaatan Teknologi Informasi Komunikasi Berbasis E-Commerce Sebagai Media Pemasaran Usaha Kecil Menengah Guna Meningkatkan Daya Saing Dalam Menghadapi Masyarakat Ekonomi Asean 2015. Economics Development Analysis Journal, 2(2), 135-139. https://doi.org/10.15294/edaj.v2i2.1401 
Kudsiah, H., Tresnati, J., \& Ali, S.A. (2018). IbM Kelompok Usaha Bandeng Segar Tanpa Duri di Kabupaten Pangkep Sulawesi Selatan. Jurnal Panrita Abdi, 2(1), 55-63.

Oktaviani, F., \& Rustandi, D. (2018). Implementasi Digital Marketing dalam Membangun Brand Awareness. PRofesi Humas: Jurnal Ilmiah Ilmu Hubungan Masyarakat, 3(1), 1. https://doi.org/10.24198/prh.v3i1.15878

Pradiani, T. (2018). Pengaruh Sistem Pemasaran Digital Marketing Terhadap Peningkatan Volume Penjualan Hasil Industri Rumahan. Jurnal Ilmiah Bisnis Dan Ekonomi Asia, 11(2), 46-53. https://doi.org/10.32812/jibeka.v11i2.45

Purwana, D., Rahmi, R., \& Aditya, S. (2017). Pemanfaatan Digital Marketing Bagi Usaha Mikro, Kecil, Dan Menengah (UMKM) Di Kelurahan Malaka Sari, Duren Sawit. Jurnal Pemberdayaan Masyarakat Madani (JPMM), 1(1), 1-17. https://doi.org/10.21009/jpmm.001.1.01

Rhohman, F., \& Budiretnani, D.A. (2018). Optimalisasi Proses Produksi Tahu untuk Peningkatan Kesejahteraan Produsen Tahu. Jurnal Panrita Abdi, 2(2), 113-118.

Penulis:

Inaya Sari Melati, Jurusan Pendidikan Ekonomi, Fakultas Ekonomi, Universitas Negeri Semarang. Email: inaya.sari@mail.unnes.ac.id

Margunani, Jurusan Pendidikan Ekonomi, Fakultas Ekonomi, Universitas Negeri Semarang. Email:margunani@mail.unnes.ac.id

Saringatun Mudrikah, Jurusan Pendidikan Ekonomi, Fakultas Ekonomi, Universitas Negeri Semarang. E-mail: saringatunmudrikah@mail.unnes.ac.id

Lola Kurnia Pitaloka , Jurusan Pendidikan Ekonomi, Fakultas Ekonomi, Universitas Negeri

Semarang. E-mail: lolakp@mail.unnes.ac.id

Bagaimana men-sitasi artikel ini:

Melati, I.S., Margunani, Mudrikah, S., \& Pitaloka, L.K. (2020). Upaya Optimalisasi Praktik Digital Marketing untuk Meningkatkan Hasil Penjualan Produk Warga Binaan Lembaga Pemasyarakatan.

Jurnal Panrita Abdi, 4(2), 155 - 163. 